\title{
Impact of Raspberry bushy dwarf virus on 'Marion' Blackberry
}

\author{
Bernadine Strik, Department of Horticulture, Oregon State University, Corvallis 97331; and Robert R. Martin,
} USDA-ARS Horticulture Crops Research Laboratory, 3420 N.W. Orchard Ave., Corvallis, OR 97330

\begin{abstract}
Strik, B., and Martin, R. R. 2003. Impact of Raspberry bushy dwarf virus on 'Marion' blackberry. Plant Dis. 87:294-296.

Raspberry bushy dwarf virus (RBDV), genus Idaeovirus, was first observed in 1997 in a planting of 'Marion' blackberry (a complex hybrid with Rubus idaeus, $R$. procerus, and $R$. ursinus in its background) established at the North Willamette Research and Extension Center (Aurora, OR) from tissue-cultured plants in 1993. RBDV was detected in 128 of the 280 plants. The incidence of RBDV in this planting did not increase from 1997 through 2001. In 1999 and 2000, we evaluated the impact of RBDV on yield, fruit quality, and plant growth of 'Marion' blackberry. RBDV had no effect on cane growth or fruit number, but it reduced yield (40 to $50 \%$ ), fruit weight (23 to $40 \%$ ), and drupelet number per fruit (36 to 39\%) compared with uninfected plants. In 2000, we surveyed 32 commercial 'Marion' fields for RBDV using enzyme-linked immunosorbent assay. The locations of sampled fields were selected to reflect the acreage distribution of 'Marion' blackberry production in Oregon. RBDV-infected plants were detected in three fields.
\end{abstract}

Oregon is the world's leading blackberry production region, averaging 18,240 metric tons of fruit harvested from 2,750 hectares in 1999 through 2001 (13). Over 92\% of the total production is processed, with the remainder being sold as fresh fruit. 'Marion' trailing blackberry (a complex hybrid with Rubus idaeus L., $R$. procerus P.J. Mill., and R. ursinus Cham. \& Schltdl. in its background; 7), 'Boysen' (a raspberry-blackberry hybrid of unknown parentage), and 'Thornless Evergreen' ( $R$. laciniatus Willd.) (14) or 'Everthornless' (11) account for 57, 19, and $17 \%$ of the planted acreage, respectively.

Raspberry bushy dwarf virus (RBDV), a seed- and pollen-borne virus (12) of the genus Idaeovirus, is relatively common in raspberry fields in the Pacific Northwest (Oregon, Washington, and British Columbia, Canada) (10). RBDV was found in $84 \%$ of 'Meeker' red raspberry ( $R$. idaeus) fields tested in northwestern Washington and southwestern British Columbia. Virus incidence in most of those fields was greater than $50 \%$ (10). In southern Washington and Oregon, 16\% of the 'Meeker' fields tested had RBDV, with none having

Corresponding author: Robert R. Martin

E-mail: martinrr@science.oregonstate.edu

* The $e$-Xtra logo stands for "electronic extra" and indicates Figure 1 appears in color in the online edition.

Accepted for publication 18 October 2002.

Publication no. D-2003-0116-01R

This article is in the public domain and not copyrightable. It may be freely reprinted with customary crediting of the source. The American Phytopathological Society, 2003. a virus incidence greater than $50 \%$ (10). RBDV infection was found in $88 \%$ of the commercially cultivated black raspberry 'Munger' (Rubus occidentalis L.) fields tested, with most of those having a high incidence of infection. In contrast, native black raspberry $(R$. leucodermis Douglas ex Torr. \& A. Gray) plants adjacent to infected commercial 'Munger' fields tested negative for RBDV (10). Finn and Martin (8) reported no RBDV infection in $R$. leucodermis seeds collected from wild coastal and mountain stands in the Pacific Northwest.

Symptoms of RBDV infection in red raspberry have varied from symptomless (1) to the production of crumbly fruit (12), reduced yield $(5,6)$, reduced cane growth, and chlorosis $(2,4,5)$. In the United States, the only blackberry reported to be infected with RBDV was 'Boysen,' and it was symptomless (1). No RBDV infection was found in clonal or seed-propagated wild blackberries ( $R$. ursinus) or in $R$. armeniacus Focke collected from wild coastal and mountain stands $(3,8)$. In New Zealand, RBDV was widespread in commercial 'Boysen' plantings (15). Also, leaf chlorosis and vein-clearing has been observed in RBDV-infected 'Marion' and 'Olallie' blackberry plants, but fruit quality and yield effects were not studied (9).

In a 1997 sampling for RBDV at the North Willamette Research and Extension Center (NWREC; Aurora, OR), we found $46 \%$ of the 'Marion' blackberry plants were infected with RBDV. The planting tested had been established in 1993 from tissue-cultured plants obtained from a commercial nursery. The tissue-cultured plants were derived from virus-tested mother plants. The objectives of this study were to determine the effects of RBDV on plant vigor, yield, and fruit quality of 'Marion' blackberry, to look at its prevalence in commercial fields, and to evaluate the rate of spread of RBDV in this planting over a 3-year period.

\section{MATERIALS AND METHODS}

Virus testing. This study was conducted in a mature 'Marion' planting at the NWREC. Plants were tested annually from 1997 through 2001, first, to establish their RBDV status prior to selecting paired plants for harvest and growth measurements, and second, to monitor the rate of RBDV spread in the planting. Three leaflets were collected per plant and pooled for testing. In 1997, the samples were tested in duplicate wells for RBDV, Tobacco streak virus (TSV), and Tomato ringspot virus (ToRSV). In subsequent years, the samples were only tested for RBDV. Known infected raspberry plants maintained in a greenhouse were used as positive controls in all of the tests.

A grower survey was done in 2000 . Thirty-two commercial 'Marion' fields were sampled and tested for the presence of RBDV using enzyme-linked immunosorbent assay (ELISA). The location of sampled fields was selected to reflect the acreage distribution of 'Marion' or based on the occurrence of suspect symptoms. In commercial plantings, single leaflets were collected from 72 individual plants per field and combined in groups of three for ELISA testing. Twenty-four leaflets were collected along each of three rows at approximately $1 / 4,1 / 2$, and $3 / 4$ of the way across the fields. Growers were asked if they were aware of any areas showing chlorosis or poor fruit set; when such areas were present, they were sampled in addition to the sampling described above in the field. Commercial fields were tested for RBDV, TSV, and ToRSV. Forty individual plants were resampled from the area in commercial fields that had RBDV-infected plants identified in the survey.

Triple antibody sandwich (TAS)-ELISA was used to detect RBDV, TSV, and ToRSV. The tests were carried out using the same procedures and antibodies as described by Finn and Martin (8). Reactions were considered positive if the $A_{405}$ values were greater than 5 times the values obtained for healthy controls and greater than 0.1. $A_{405}$ values of healthy samples ranged from 0.00 to 0.05 .

Fruit and plant growth evaluations. Yield and growth studies were conducted 
on 17 and 15 infected and noninfected, paired, side-by-side plants in 1999 and 2000, respectively. The RBDV status of each plant was confirmed by ELISA after fruit harvest in 1999 and 2000. Plants were trained in August 1998 and 1999 such that individual plant yield could be obtained in 1999 and 2000. On 30 June 1999 and on 21 June 2000, the total number of primocanes (current year nonfruiting canes) per plant was counted; two long and two short representative canes were measured for length, and a weighted mean was calculated. On 21 June 2000, total primocane number and total length per plant were determined. In 1999 and 2000, fruit were hand harvested about every 5 days from each plant. A randomly collected 50-berry subsample was weighed from each harvest to obtain average berry weight in each year; a weighted average berry weight was calculated. Ten of the 50 berries were subsampled, and total drupelet number was counted in each year. Drupelet number was counted to determine if RBDV has a similar effect on blackberry as has been reported for RBDV infection in red raspberry. Data were analyzed using a paired $t$ test for each year (Version 6.2, SAS Institute Inc., Cary, NC).

\section{RESULTS}

Virus testing. The incidences of RBDV in the 'Marion' planting established from tissue-cultured plants in 1993 were $128 / 280,128 / 280,128 / 280,130 / 280$, and $130 / 280$ in 1997 to 2001, respectively. Visual symptoms of RBDV infection were apparent on some of the infected plants in all 5 years. Some primocane leaves of all ages showed chlorosis and vein-clearing later in the growing season; leaves on the fruiting canes were often chlorotic and were silver in color on the abaxial surface; and fruit were malformed and small on infected plants (Fig. 1). The severity of fruit symptoms appeared to vary each year, with severely affected fruit having a mean of 10 to 12 drupelets compared with a mean of 60 drupelets present in the fruit from RBDV-negative plants.

Of the 32 commercial 'Marion' blackberry fields sampled, three contained RBDV-infected plants, one each in Marion, Polk, and Multnomah counties. All the fields tested were more than 15 years old. Of the infected fields, one had red raspberries planted nearby (less than $100 \mathrm{~m}$ ), another had red raspberries located about 0.5 $\mathrm{km}$ away, and the third was propagated using cuttings from a field that had a low level of RBDV positives, although it was not known to be RBDV-infected at the time the cuttings were taken. The 'Marion' fields found to be infected with RBDV had only a low level of infection in terms of number of plants infected per number sampled. When resampling the areas of commercial fields where the virus was detected, the number of infected plants ranged from 6 to 15 out of 40 plants tested.
Fruit and plant growth evaluations. There was no statistically significant effect of RBDV on cane number or length in either year (data not shown). Yield was low in 1999, even on uninfected plants, due to winter damage. However, RBDV infection reduced yield $50 \%$, berry weight $40 \%$, and drupelet number per berry $39 \%$ (Table 1). There was no statistically significant effect of RBDV on fruit number. Yield from uninfected plants was 23 times greater in 2000 than in 1999, as there was no winter cold injury in 2000 . In 2000, RBDV infection reduced yield $40 \%$, berry weight $23 \%$, and drupelet number $36 \%$ (Table 1).

\section{DISCUSSION}

Our results show that RBDV had no effect on fruit number or cane growth in reported in some red raspberry cultivars (4-6). RBDV infection reduced yield (40 to $50 \%$ ), berry weight (23 to $40 \%$ ), and drupelet number per fruit (36 to $39 \%$ ). Thus, RBDV infection in 'Marion' has a 'Marion' blackberry, unlike what has been

similar effect on yield and quality as has been reported in some red raspberry cultivars $(5,6,12)$. There was no chlorosis present early in the season, but by early July as the fruit was ripening, the chlorosis on both primocanes and fruiting canes was very striking.

Our survey of the commercial 'Marion' blackberry industry in Oregon has shown that RBDV is present in some grower fields. The fields that did have RBDV had a low level of infection, and the infected plants were clustered in small areas of the fields. This suggests several possibilities: first, that the virus has been in 'Marion' for quite some time and moves very slowly in this crop; second, that there has been a recent mutation in RBDV that now is able to infect 'Marion' blackberry; or third, that plant breeders have been making hybrids between raspberry and blackberry and the RBDV could have been introduced into the hybrids through pollen transmission. The pollen from the hybrid may be much more likely to pollinate blackberry than pollen

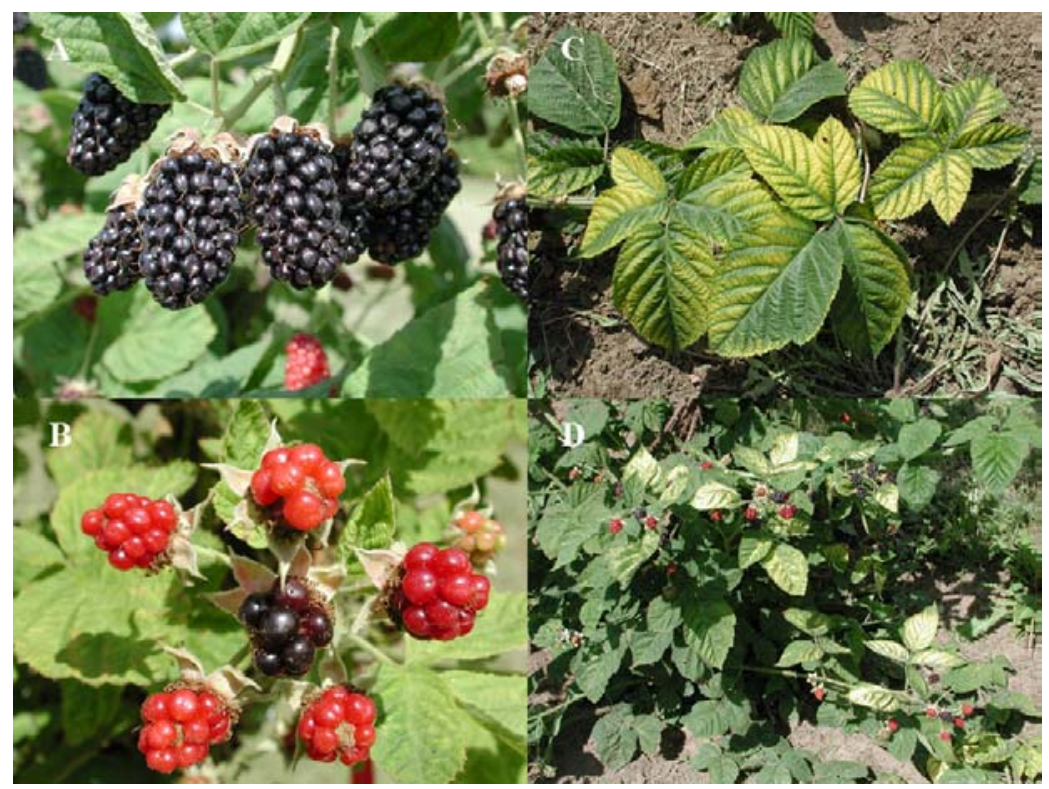

Fig. 1. Raspberry bushy dwarf virus (RBDV) symptoms in 'Marion' blackberry: A, fruit on healthy RBDV - plants; B, extremely crumbly fruit on RBDV + plants; C, leaf chlorosis on leaves of primocanes; and $\mathbf{D}$, leaf chlorosis on fruiting canes.

Table 1. The effect of Raspberry bushy dwarf virus (RBDV) infection on yield, fruit weight, and drupelet number of 'Marion' trailing blackberry in 1999 and 2000

\begin{tabular}{|c|c|c|c|c|}
\hline Treatment & $\begin{array}{c}\text { Total yield } \\
\text { (kg/plant) }\end{array}$ & $\begin{array}{c}\text { Fruit weight } \\
\text { (g) }\end{array}$ & $\begin{array}{c}\text { Drupelet }^{\mathrm{x}} \\
\text { no./fruit }\end{array}$ & Fruit no. \\
\hline \multicolumn{5}{|l|}{1999} \\
\hline RBDV-infected & 0.13 & 1.7 & 36.6 & 51.4 \\
\hline Noninfected & 0.25 & 2.9 & 59.8 & 58.9 \\
\hline Significance $^{\mathrm{z}}$ & $* *$ & $* * *$ & $* * *$ & NS \\
\hline \multicolumn{5}{|l|}{2000} \\
\hline RBDV-infected & 3.43 & 3.3 & 38.7 & $\ldots$ \\
\hline Noninfected & 5.65 & 4.3 & 60.7 & $\ldots$ \\
\hline Significance $^{\mathrm{z}}$ & $* * *$ & $* * *$ & $* * *$ & $\ldots$ \\
\hline
\end{tabular}

${ }^{\mathrm{v}}$ Total yield represents all harvests.

${ }^{\mathrm{w}}$ Based on a 50-berry sample from each harvest.

${ }^{\mathrm{x}}$ Based on a 10-berry subsample.

y An average of fruit number per plant on first and third harvests in 1999; no data collected in 2000.

$\mathrm{z} * *, * * *$, significant at $P \leq 0.01$ and $P \leq 0.001$; and NS, nonsignificant. 
from a red raspberry, thus allowing for pollen transmission of RBDV to 'Marion' blackberry. 'Marion' blackberry has been grown in Oregon for over 40 years, and the symptoms are so dramatic that growers would likely have noticed the disease if it had been in 'Marion' for a long time. However, although almost $50 \%$ of a 'Marion' blackberry planting established from tissue-cultured plants (derived from virus-tested mother plants) at the NWREC was infected 4 years after planting, there was essentially no spread of the virus from 1997 to 2001. It is possible that RBDV does not move rapidly in 'Marion' in most years but that under specific environmental conditions during the bloom period it can spread rapidly within a field. The role of environmental conditions on spread of RBDV in raspberry may explain the dramatic differences observed in rates of infection in raspberry fields in the Pacific Northwest (10).

Another explanation for the infection of 'Marion' blackberry in recent years is that the bloom period of red raspberry may now overlap that of 'Marion.' One of the goals of the raspberry breeding programs in the Pacific Northwest is to develop cultivars that produce earlier and later than the peak season in order to provide a longer season for locally grown fresh raspberries. As a result of the season extension in red raspberries, it is possible that pollen transmission of RDBV from red raspberry to blackberry may now occur because of an overlap in their bloom periods.

Although this study was carried out on 'Marion' blackberry, similar leaf and fruit symptoms were observed on other selections of the trailing blackberry at the NWREC. Testing the plants by ELISA confirmed the presence of RBDV in the symptomatic selections and also showed that some symptomless selections tested positive by ELISA.

\section{ACKNOWLEDGMENTS}

The authors acknowledge the support of the Oregon Raspberry and Blackberry Commission and the assistance of Sophie Somnard and Caroline Godard (Interns, INA P-G, France), Jason Lett (former Research Assistant, NWREC), and Gil Buller (Research Assistant, NWREC).

\section{LITERATURE CITED}

1. Converse, R. H. 1973. Occurrence and some properties of raspberry bushy dwarf virus in Rubus species in the United States. Phytopathology 63:780-783.

2. Converse, R. H. 1977. Rubus virus diseases important in the United States. HortScience 12:471-476.

3. Converse, R. H., and Bartlett, A. B. 1979. Occurrence of viruses in some wild Rubus and Rosa species in Oregon. Plant Dis. Rep. 63:441-444.

4. Converse, R. H., and Casper, R. 1977. Raspberry bushy dwarf virus in cultivated red raspberry in Germany. Phytopathol. Z. 89:187-190.

5. Daubeny, H. A., Freeman, J. A., and StaceSmith, R. 1982. Effects of raspberry bushy dwarf virus on yield and cane growth in susceptible red raspberry cultivars. HortScience
17:645-647.

6. Daubeny, H. A., Stace-Smith, R., and Freeman, J. A. 1978. The occurrence and some effects of raspberry bushy dwarf virus in red raspberry. J. Am. Soc. Hortic. Sci. 103:519522.

7. Finn, C., Strik, B., and Lawrence, F. 1997. 'Marion' trailing blackberry. Fruit Var. J. 51:130-133.

8. Finn, C. E., and Martin, R. R. 1996. Distribution of tobacco streak, tomato ringspot, and raspberry bushy dwarf viruses in Rubus ursi$n u s$ and $R$. leucodermis collected from the $\mathrm{Pa}$ cific Northwest. Plant Dis. 80:769-772.

9. Jones, A. T., Murant, A. F., Jennings, D. L., and Wood, G. A. 1982. Association of raspberry bushy dwarf virus with raspberry yellows disease; reaction of Rubus species and cultivars, and the inheritance of resistance. Ann. Appl. Biol. 100:135-147.

10. Martin, R. R. 1999. Raspberry viruses in Oregon, Washington and British Columbia. Acta Hortic. 505:259-262.

11. McPheeters, K., and Skirvin, R. M. 2000. 'Everthornless' blackberry. HortScience 35:778-779.

12. Murant, A. F., Chambers, J., and Jones, A. T 1974. Spread of raspberry bushy dwarf virus by pollination, its association with crumbly fruit and problems of control. Ann. Appl. Biol. 77:271-281.

13. Oregon Agriculture and Fisheries Statistics 2000-2001. U.S. Dep. Agric. Nat. Agric. Stat. Serv., Oreg. Dep. Agric. Pap. 52. Also published online.

14. Waldo, G. F. 1977. 'Thornless Evergreen' Oregon's leading blackberry. Fruit Var. J. 31:26-30.

15. Wood, G. A. 1995. Further investigations of raspberry bushy dwarf virus in New Zealand. N.Z. J. Crop Hortic. Sci. 23:273-281. 